Review

\title{
Current state of chronic wound care in Kazakhstan: focus on topical treatments
}

\author{
Alma Akhmetova ${ }^{1}, \operatorname{Timur}$ Saliev ${ }^{1}$, Gulsim Kulsharova ${ }^{1}$, Talgat Nurgozhin ${ }^{1}$, Sergey Mikhalovsky ${ }^{1,2}$ \\ ${ }^{1}$ Nazarbayev University, Astana, Kazakhstan \\ ${ }^{2}$ University of Brighton, Brighton, United Kingdom
}

Received 10 December 2014, Accepted 16 January 2015

(C) 2014, Akhmetova A., Saliev T., Kulsharova G., Nurgozhin T., Mikhalovsky S.

(C) 2014, Russian Open Medical Journal

Abstract: Background - The presence of chronic hard-to-heal wounds significantly affects patients' quality of life causing pain, discomfort, decrease of mobility and consequently leads to social isolation and depression. This type of wound is more prevalent among older population. It has been estimated that up to $1-2 \%$ of the world population have this condition. The treatment of hard-to-heal wounds is expensive and long-term process, and, stresses healthcare systems of every country. Unfortunately, limited information is available about the situation with chronic wounds in Kazakhstan as the statistical data on such patients is not monitored and not registered in this country. Methods - The search was conducted by using available electronic sources, including Google Scholar, PubMed, Web of Sciences, Medline, Wiley Online Library, and Cochrane Library databases as well as hard copy versions of peer-reviewed publications in Russian, Kazakh, and English languages.

Results - We have identified and analyzed current situation with wound care in the Republic of Kazakhstan. Research has demonstrated a variety of types of treatments utilized in the country, particularly the treatment of the diabetic foot.It also indicates the lack of statistics on wound care.

Conclusions - The review highlights the mechanisms of wound healing process, methods for wound care, and encompasses the information available on wound healing in Republic of Kazakhstan. The article emphasizes the necessity of establishing the systemic monitoring of wound care and formation of electronic database. Apart from that, the importance of developing and manufacturing of domestic novel wound treatments have been also stressed out.

Keywords: chronic wound, treatment, wound dressing, Kazakhstan

Cite as Akhmetova A, Saliev T, Kulsharova G, Nurgozhin T, Mikhalovsky S. Current state of chronic wound care in Kazakhstan: focus on topical treatments. Russian Open Medical Journal 2015; 4: e0104.

Correspondence to Timur Saliev. Address: Department of Regenerative Medicine and Artificial organs, Center for Life Sciences, Nazarbayev University Unit 9, 53 Kabanbaybatyr Ave., Astana 010000, Kazakhstan. Tel.: +7 (7172) 7093 07. Email: tim.saliev@gmail.com

\section{Introduction}

Chronic ulcers represent a great burden to healthcare systems worldwide. The estimated number of people suffering from this condition reaches $1-2 \%$ of world population [1]. Although there is no agreed definition of chronic wounds, they have been usually described as wounds that were not able to heal within a certain period of time $[1,2]$. The major types of chronic wounds are venous leg ulcer, diabetic foot, and pressure ulcer [1]. These wounds are mostly prevalent in older population and are often caused by underlying health problems such as diabetes, vascular diseases, or obesity $[1,3,4]$.

For Kazakhstan, no collection of data for statistical analysis on the prevalence of chronic wounds has been conducted for the whole country. Therefore, several reports of doctors from different regions of Kazakhstan were referring to the number of patients accepted annually in local hospitals to describe the prevalence of hard-to-heal wounds. For example, Negemedjanov
[5] wrote that around 17-19 patients with chronic wounds were treated annually in Petropavlovsk hospital. However, since not every hospital accepts and treats chronic ulcers, a rough assumption on the prevalence can only be made based on the number of people with diabetes in Kazakhstan. The prevalence of diabetes increased up to 1.6 times between 2000 and 2010 [6]. In 2013 , there were around 526,010 cases of diabetes in adults in Kazakhstan [7]. It is estimated that around $25 \%$ of patients with diabetes develop chronic ulcers during their life [8]. Thus, it may be roughly assumed that at the moment more than 130 thousand people with diabetes in Kazakhstan may have or will develop chronic skin ulcers. Moreover, this number may increase over time due to the growth of general and older population size.

This is the first review article that is written with the purpose of increasing public awareness and describing the current situation of chronic wound care in Kazakhstan. 
Table 1. Details of the search strategy

\begin{tabular}{|c|c|c|}
\hline Searched words & \multicolumn{2}{|r|}{ Sources and places of search } \\
\hline \multirow{4}{*}{$\begin{array}{l}\text { Wound, } \\
\text { chronic wound, } \\
\text { septic wound, } \\
\text { trophic ulcer, } \\
\text { bed sores, } \\
\text { diabetic foot, } \\
\text { leg ulcer, } \\
\text { Kazakhstan }\end{array}$} & Journals & $\begin{array}{l}\text { Consilium*, Medicine*, Vestnik KazNMU*, KazNU Bulletin Biology series*, Astana Medical Journal*, } \\
\text { Terapevticheskyi Vestnik*, Vestnik Hirurgii Kazahstana, Aktual'nye voprosy formirovanija zdorovogo } \\
\text { obraza zhizni, profilaktiki zabolevanij i ukreplenija zdorov'ja, Farmatsiya Kazakhstana, Vestnik Evraziyskogo } \\
\text { natsional'nogo universiteta, Densawli'k }\end{array}$ \\
\hline & Libraries & National Academic Library of the Republic of Kazakhstan*, Nazarbayev University Library* \\
\hline & Databases & $\begin{array}{l}\text { Web of Science, PubMed, Cochrane Library, Wiley Online Library, Medline, Google Scholar, } \\
\text { www.articlekz.com }\end{array}$ \\
\hline & Websites & $\begin{array}{l}\text { www.dari.kz, www.zdrav.kz, www.e-library.kz, Journal of Clinical Medicine of Kazakhstan*, East } \\
\text { Kazakhstan Regional Library (www.pushkinlibrary.kz), Republican Scientific and Technical Library } \\
\text { (www.rntb.kz), www.google.com }\end{array}$ \\
\hline
\end{tabular}

* Sources that contained necessary articles or information that was included in this review.

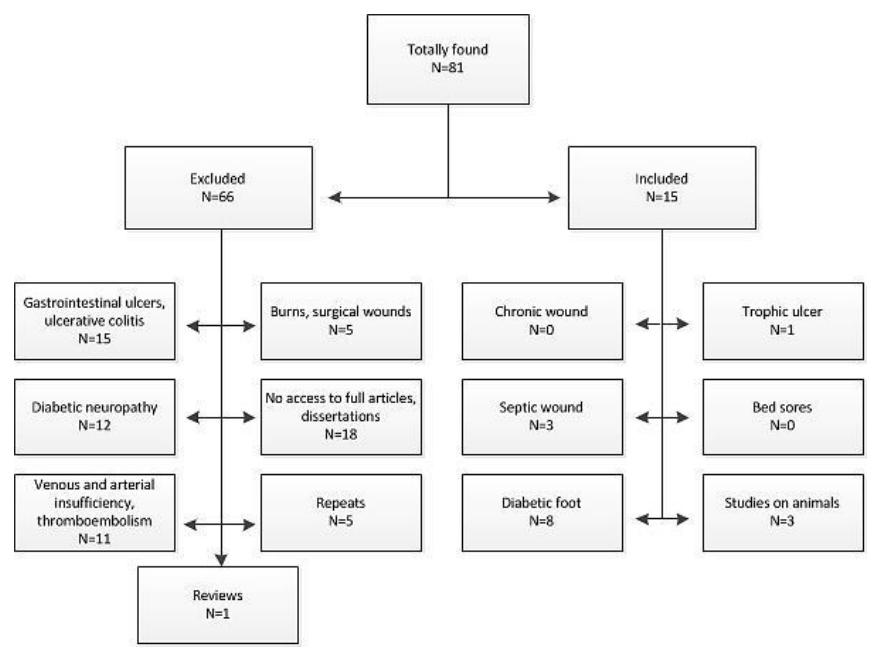

Figure 1. Inclusion and exclusion criteria of the articles found

\section{Material and Methods}

\section{Search strategy}

The search was conducted online using Google Scholar, PubMed, Web of Sciences, Medline, Wiley Online Library, and Cochrane Library databases and hard copy versions of peerreviewed publications in Russian, Kazakh, and English languages. The search of hard copies was restricted to libraries in the Astana city. The keywords for search were: wound, chronic wound, septic wound, trophic ulcer, bed sores, diabetic foot, leg ulcer, and Kazakhstan. Table 1 shows words used for search and sources of articles. None of the well-known databases revealed papers of interest related specifically to Kazakhstan. The websites have limited information most of which is not referenced or contains student dissertations with restricted or no access.

Figure 1 demonstrates inclusion and exclusion criteria and the number of articles found in each category. Note that only one review articles was found, but it was not included because it was not related to Kazakhstan. Most of the articles were case studies conducted in hospitals with no reference to previous studies in vitro or in vivo or to their ethical approval.

\section{Ethics issues}

The conducted research did not involve any human subjects, including human material or human data.The research was solely restricted to available data bases: electronic and printed.

\section{Wound healing and its mechanism}

A wound healing is complex by nature and the processes underlying it are not well understood to the date. Healing of normal wound is usually described in three $[9,10]$ or four overlapping stages (depending on the source of the information) $[3,4,11]$ : homeostasis, inflammation, proliferation, and remodeling. A normal woundstuck in the inflammation phase and unable to proceed to further stages of healing in a certain period of time becomes chronic [10]. During a prolonged inflammation phase the inflammatory cytokines and white blood cells not only debride wound of necrotic tissue and bacteria, but can also damage surrounding healthy tissues, thus preventing the wound from closing and by that delaying its healing. To address this problem various treatment strategies have been proposed worldwide depending on the healing stage and etiology of the wound $[2,12]$. To accelerate healing process a wound should be debrided regularly, kept moisturized, protectedfrom further trauma and bacterial contamination. To achieve this, clinicians have been utilizing various types of dressings, gels, sprays, and antibiotics. These components have been used in different combinationsin order to optimize the wound management.

In general, all dressings do provide a barrier to contamination. Due to variety of materials, there is a wide choice for a clinician to choose an appropriate dressing for particular woundtype $[13,14]$. At present dressings made of polymer materials can be impregnated by different agents such as charcoal $[15,16]$, silver $[17,18]$, iodine $[19,20]$, and honey [21]. Properties of the material and the enclosed agent do determine the application of the dressing. The material can be presented by hydrogels, hydrocolloids, foams and films. Each of these materials with or without incorporated agents have specific mode of action aimed at either killing bacteria, absorbing exudate, or facilitating cell proliferation and wound closure.

Gels and ointments have paste-like consistency and are commonly used in combination with dressings to immobilize them. They usually contain a single active ingredient such as metronidazole [22-24], honey [25, 26], silver [27], growth factors [28], iodine [29], or sugar [30, 31]. However, due to dilution with wound exudate gels and ointments become less effective and can cause the leakage through the dressing [32]. This in turn leads to more frequent re-application and dressing changes, which may not be cost-effective. Apart from that, their use might also provoke discomfort or pain.

For infection control, topical and systemic administration of antibiotics has beenextensively used for infected or heavily contaminated wounds [33]. However, sometimes bacteria could develop a resistance against both topical and systemic antibiotics. 
Often these cases have been associated with biofilms, bacterial communities that share common properties such as drug resistance $[1,34]$. Therefore, there is an ongoing search for natural and chemical substances that can be used as an alternative to antibiotics. For example, it has been demonstrated that honey affects differently each bacterial strain, thus preventing the development of resistance [35]. Iodine [36], sugar [30, 32] or silver $[18,37-39]$ have also been widely used for antibacterial purposes.

\section{Wound care in Kazakhstan}

Kazakhstan is considered as a country in transition, which is a status of the country between developing and developed countries. The countryhas been ranked amongst the fastest growing world economies last decade. Despite the challenges of first years of independence, the national Health Care system remains the efficient and functional. It undergoes a systematic revision and optimization. The reforms have been focused on implementation of modern technologies for disease control, early detection, treatment and rehabilitation; strengthening the links between medical research and its practical applications in the health sector; development of international partnerships; integration of medical science, education and practice; monitoring and evaluation of health reform initiatives; and implementation of evidence-based medicine [40].

In comparison to developed countries, little is known about wound care system and available treatment options for chronic wounds in Kazakhstan. For instance, a recent study assessed public opinion and awareness of diabetic foot care, a type of chronic wound, in Almaty region [41]. The survey of 462 people identified the most common ten false statements given by patients, healthy individuals, and even medical personnel. More than $60 \%$ of interviewees showed poor knowledge of the subject, including medical personnel. Over $80 \%$ of all responders believed that there was no treatment available in Kazakhstan, and $69 \%$ said that amputation was an inevitable consequence of the treatment of diabetic foot.

However, some progress in the wound care system can be observed from the available publications. Recently, the number of works in the field of wound care has increased. These articles indicate that the offices for diabetic foot care have been opened in the past few years in several cities and at least requested in others [42]. It must be noted he infection of diabetic wounds plays an important role in developing complications and worsening health state of the patient. In this context, the infection control and monitoring are essential for wound management. To achieve this, microbiological assessment of wound exudates has been obtained from patients was carried out in some hospitals [43-45]. Often there was no description of microbiological tests used in the studies [43], but in [46] Gram staining and Micro-LA-Test (STAPHYtest16, NEFERMtest24, CANDIDAtest21) were used to assess wound swabs and then develop phyto-preparations against identified microorganisms. In some cases microbiological tests were not conducted prior to antibiotic treatment. For example, in Aktau [47] and in Petropavlovsk [5] doctors used loading dose of antibiotics for a wide range of microorganisms before both assessing wound micro-flora and testing patients for allergies and their sensitivity to these drugs. This was explained by the lack of time required to get the results and the urgency to start the treatment. The targeted antibiotics were prescribed after obtaining test results.

\section{Topical treatments}

Majority of publications describe case studies or case series regarding compounds manufactured locally or imported from abroad. Below is a brief summary of the types of medicines tested in Kazakhstan.

\section{Ointments}

\section{Phytopreparations}

Products developed in Kazakhstan for treatment of chronic wounds are mostly phyto-preparations. They come in the form of gels and ointments prepared from plant extracts. There is limited information online (or in hard copy) about these compounds, and apparently none of them are marketed yet.

The Institute for Phyto-chemistry located in Karaganda is actively involved both in the research of active components with regenerative ability found in plant extracts and development of ointments and dressings for wounds of various etiologies. The study by Bekmoldina [43] assessed Topolin and Calior ointments developed at the Institute of Phyto-chemistry for their antimicrobial efficacy. 408 strains from over 300 patients with septic and trophic wounds were identified. According to her analysis dominant species were Staphycoccus spp., Streptococcus spp., and Enterobacter spp. Both of the ointments decreased the number of beta-haemolytic Streptococci and Enterococcus faecalis, and the number of Staphylococcus aureus and Staphylococcus epidermidis dropped twice. However, due to superinfection the number of Enterobacteriaceae was increased.

Another study compared the effect of three Kazakhstani phyto-preparations on acute and trophic wounds on rats [48]. All three preparations contained several bioactive components and were claimed to be multifunctional. Recently, Eurasian National University in Astana has claimed to have developed a new timeand cost-saving method for extraction of phenol compounds from 15 different Europhorbiaceaes pp. [49]. However, the method was not described. Based on this technology Suttigen ointment was developed. Suttigen, which contains extract of Eurhobia Soongarica, demonstrated antimicrobial activity against strains extracted from septic wounds [50]. 3\% Suttigen ointment decreased $S$. aureus from $10^{7}-10^{8}$ to $1 \times 10^{4}$ per $1 \mathrm{~cm}^{2}$. The author stated that this ointment cleared wounds almost twice faster and aided healing process better than Levomekol, or Laevomecolum (chloramphenicol + methyluracil) or $10 \%$ methyluracil ointments, which are often used in hospitals.

The study by Mukhambetov et al. [48] on rats showed that healing of acute and trophic wound was better in terms of epithelization and formation of granulation tissue using Lipophyt (extract of Milfoil spissum + oil of the mixture of several plants) or Topolin (Populus Nigra or Populus Balsamifera bud extract) rather than Suttigen. Acute wounds healed within 15-16 days using either Suttigen, or Lipophyt, or Topolin. Healing of trophic wounds in rats was more challenging. There was also no indication of wound closure time in the article published. 
Table 2. The list of studies and topical treatments used to heal chronic or septic wounds in Kazakhstan

\begin{tabular}{|c|c|c|c|c|c|c|c|}
\hline № & Intervention & Manufacturer, country & Description & Application & Location of the study & $\begin{array}{c}\text { Market } \\
\text { availability }\end{array}$ & Ref. \\
\hline 1 & Pinosorb & \multirow{2}{*}{$\begin{array}{l}\text { Institute for } \\
\text { Phytochemistry, } \\
\text { Karaganda, } \\
\text { Kazakhstan }\end{array}$} & Dressing: pine pitch with sorbent & \multirow[b]{2}{*}{ Trophic ulcers } & \multirow[b]{2}{*}{ Karaganda Hospital } & N/A & \multirow[b]{2}{*}{ [53] } \\
\hline 2 & Bialm & & Ointment: $30 \%$ pine pitch & & & N/A & \\
\hline 3 & Levomekol & Nizhpharm, Russia & $\begin{array}{ll}\text { Ointment: } & \text { levomycetin } \\
\text { (Chloramphenicol) } & \end{array}$ & $\begin{array}{l}\text { Septic wounds, } \\
\text { chronic ulcers }\end{array}$ & $\begin{array}{l}\text { National Scientific- } \\
\text { Medical Center, } \\
\text { Astana Polyclinic №6 }\end{array}$ & A & [44] \\
\hline 4 & $\begin{array}{l}\text { Collagen film } \\
\text { with cells }\end{array}$ & $\begin{array}{l}\text { Astana Polyclinic №6, } \\
\text { Kazakhstan }\end{array}$ & $\begin{array}{l}\text { Dressing: collagen film with } \\
\text { fibroblasts and keratinocytes }\end{array}$ & Trophic ulcers & & N/A & \\
\hline 5 & Argosulfan & Jelfa S.A., Polland & $\begin{array}{l}\text { Ointment: silver sulfathiazole } \\
\text { salts }\end{array}$ & $\begin{array}{l}\text { Chronic ulcerative } \\
\text { pyoderma }\end{array}$ & $\begin{array}{l}\text { Karaganda Regional } \\
\text { Dermatovenerologic } \\
\text { Dispensary }\end{array}$ & A & [54] \\
\hline 6 & Bioptron & Zepter, Switzerland & $\begin{array}{l}\text { Device: polarized light in visible } \\
\text { and near-infrared range } 450-2000 \\
\mathrm{~nm}\end{array}$ & Trophic leg ulcers & $\begin{array}{l}\text { Research and } \\
\text { Development } \\
\text { Institute of } \\
\text { Dermatovenerology, } \\
\text { Almaty }\end{array}$ & A & [43] \\
\hline 7 & Topolin & $\begin{array}{l}\text { Pharmaceutical Plant, } \\
\text { Karaganda, } \\
\text { Kazakhstan }\end{array}$ & Ointment: phytopreparation, 5\% & Trophic ulcers & \multirow{3}{*}{$\begin{array}{l}\text { Astana: Medical } \\
\text { University, Republic } \\
\text { Collection of } \\
\text { Microorganisms, } \\
\text { Tselinograd } \\
\text { Supraregional } \\
\text { Clinical Hospital. } \\
\text { Kokshetau: Aqmola } \\
\text { Regional Hospital }\end{array}$} & $A^{*}$ & \multirow{3}{*}{ [47] } \\
\hline 8 & Lipophyt & $\begin{array}{l}\text { Production } \\
\text { Cooperation } \\
\text { "Kyzylmai", Almaty, } \\
\text { Kazakhstan }\end{array}$ & $\begin{array}{l}\text { Oleogelphytopreparation, } \\
\text { contains beeswax }\end{array}$ & & & $A^{*}$ & \\
\hline 9 & Suttigen & $\begin{array}{l}\text { L.N.Gumilyov Eurasian } \\
\text { National University, } \\
\text { Astana, Kazakhstan }\end{array}$ & $\begin{array}{l}\text { Ointment in the form of powder } \\
\text { that contains extract of } \\
\text { Euphorbia soongarica }\end{array}$ & & & N/A & \\
\hline 10 & Regen-D 150 & $\begin{array}{lr}\text { Bharat } & \text { Biotech } \\
\text { International Ltd, India }\end{array}$ & $\begin{array}{l}\text { Gel: contains epidermal growth } \\
\text { factor (EGF) }\end{array}$ & Trophic ulcers & $\begin{array}{l}\text { Almaty Multi-Field } \\
\text { Hospital }\end{array}$ & A & [50] \\
\hline 11 & Calior & $\begin{array}{l}\text { Institute for } \\
\text { Phytochemistry, } \\
\text { Kazakhstan }\end{array}$ & $\begin{array}{l}\text { Ointment: antiseptic from } \\
\text { marigold }\end{array}$ & \multirow{2}{*}{$\begin{array}{l}\text { Trophic ulcers and } \\
\text { septic wounds }\end{array}$} & \multirow{2}{*}{$\begin{array}{l}\text { Karaganda Regional } \\
\text { Medical Hospital }\end{array}$} & N/A & \multirow{2}{*}{ [42] } \\
\hline 12 & Topolin & $\begin{array}{l}\text { Pharmaceutical Plant, } \\
\text { Karaganda, } \\
\text { Kazakhstan }\end{array}$ & Ointment: phytopreparation, $30 \%$ & & & $A^{*}$ & \\
\hline 13 & Tachocomb & Nycomed, Austria & Dressing:fibrinogen and thrombin & $\begin{array}{l}\text { Septic and necrotic } \\
\text { wounds }\end{array}$ & $\begin{array}{l}\text { Petropavlovsk } \\
\text { Regional Hospital }\end{array}$ & A & [44] \\
\hline 14 & Cimekol & $\begin{array}{lr}\text { S.D.Asphendiyarov } \\
\text { National } & \text { Medical } \\
\text { University } & \text { of } \\
\text { Kazakhstan, } & \text { Almaty, } \\
\text { Kazakhstan } & \\
\end{array}$ & $\begin{array}{l}\text { Antiseptic ointment based on } \\
\text { ciminal }\end{array}$ & $\begin{array}{l}\text { Septic and necrotic } \\
\text { wounds }\end{array}$ & $\begin{array}{l}\text { S.D.Asfendiyarov } \\
\text { National Medical } \\
\text { University of } \\
\text { Kazakhstan, Almaty }\end{array}$ & N/A & [51] \\
\hline
\end{tabular}

* Marketed for animal use only

\section{Growth factors}

No data was found concerning the development of wound treatments using growth factors in Kazakhstan. From the imported ointments a case study of assessing the Indian ointment Regen-D 150 was published [51]. Its active ingredient is epidermal growth factor that is potentially able to stimulate migration of cells. The study was conducted on 12 patients with trophic wounds. All patients in the treated group were healed within 4-7 weeks. Since the addition of growth factors into gels results in a relatively small increase of their efficiency in stimulating the healing process, to date the only one gel containing platelet derived growth factor, Becaplermin has been approved by FDA (U.S. Food and Drug Administration) [28]. The author did not comment on the results of the previous test studies of Regen-D and the reason this ointment was chosen for patient treatment in Kazakhstan.

\section{Other}

Kazakh National Medical University n.a. S.D. Asfendiyarov (Almaty, Kazakhstan) has developed an antiseptic ointment Ciminalum, or Ciminal, whose active ingredient is $p$-nitro- $\alpha$ chlorocinnamaldehyde, a molecule similar to levomycetin[52]. Ciminal was previously shown to have antimycotic activity against Candida and antibacterial properties against E. coli and Proteus.

\section{Biomedical devices}

Some hospitals rather use medical devices that emit light or sound at certain wavelengths. For instance, bioptron lamp that emits polarized light in the visible and infrared spectrum was tested [44]. This phototherapy was claimed to have regenerative, anti-inflammatory, and analgesic effects.

An ultrasound device of low frequency Sonoca-400 was used on septic wounds [53]. Although there is no description of the 
study, the authors claimed that granulation appears on the sixth day and epithelialization on the $10^{\text {th }}$ day. Power, time, and the working solution were chosen depending on the etiology and duration of the wound, and sensitivity of the patient.

\section{Dressings}

A collagen film impregnated with fibroblasts and keratinocytes was developed at the National Scientific-Medical Center in Astana, Kazakhstan [45]. Prior to incorporation into the dressing the culture of embryonic fibroblast cells was tested for carcinogenic properties, acquired immune deficiency syndrome (AIDS), hepatitis, and herpes. The collagen matrix was tested for pyrogenicity and toxicity. The study was conducted on 40 patients, 20 of which were in the test group. The authors demonstrated higher decrease both in pain and discomfort in comparison to the control group. However, there was no data on wound regenerative progress and wound closure.

Two imported dressings were tested at a hospital in Petropavlovsk, Kazakhstan [5]. Negemedjanov used a negative pressure compression (gauze with polymers) to reduce pressure at the wound site and highly adhesive dressing Tachocomb. Unfortunately, the study poorly described these dressings.

Table 2 summarizes the description of the above mentioned treatments tested in Kazakhstan. Currently only imported products are commercially available on the market.

\section{Challenges and Limitations}

The major limitation of this study was the lack of online available publications. Many links to access online articles from the searched websites were inactive. Most of the medical journals were only available in hard copy. All found published articles were solely in Russian or Kazakh languages, and only a few of them contained abstracts in English. Moreover, majority of the journals included are not peer-reviewed. Table 3 shows that most of the studies were concentrated on the diabetic foot ulcer excluding other types of chronic wounds.

Apart from that, the limitations of the studies conducted in Kazakhstan include the absence of randomized clinical studies, small sample size, and lack of control treatment. In terms of ethics, only patient consent letters were signed, and no indication was provided on ethical approval of the studies. A few case studies and case series were found to provide incomplete data on the study description, methods and results, such as patients' age, description of wound, previous treatments, prescribed antibiotic therapy, and statistical analysis of the data. Moreover, the data in these studies were often given in incomplete form, which makes it difficult to assess the quality of the research methodology and draw conclusions based on the obtained results.

The one of main problems of Kazakhstan's Health Care system, and particularly wound management, is an absence of universal database and access of clinicians to such infromation. The establishing the electronic database would lead todeveloping optimal wound treatment protocols,improving research methodology, creating universal patients' data lists and stimulating the knowledge exchange between clinicians across the country.
Table 3. Areas of focus of studies in Kazakhstan

\begin{tabular}{|l|c|}
\hline \multicolumn{1}{|c|}{ Type of wound } & Studies \\
\hline Diabetic foot & {$[5,40,41,45,55-60]$} \\
\hline Leg ulcer & - \\
\hline Bed sore & - \\
\hline Chronic wound & - \\
\hline Trophic ulcer & {$[42-44,47,50]$} \\
\hline Septic wound & - \\
\hline
\end{tabular}

\section{Conclusion}

This study provides a review of current situation with wound care in the Republic of Kazakhstan, highlighting an importance of monitoring and formation of comprehensive database on wound statistics. Market research and literature analysis has demonstrated development and assessment of products and treatment options for wound care. For instance, the gels containing growth factor, different dressings and medical devices have been already tested in few studies. Active search and production of phyto-preparations is in progress at local research centres. However, none of the above products reached the market yet; and there is lack of official approval for their use on chronic wounds. It caused by weak interaction between science and industry at Kazakhstan. The situation is similar to other countries from Central Asia and to former Soviet Union region as well.

According to the data available online and in hard copy, local hospitals have been using different treatment strategies available in their region. These are mostly injections, ointments and gels, which are applied with gauze to fix them in place. Moreover, all of the published interventions and treatment strategies are predominantly focusedon the diabetic foot excluding other types of chronic ulcers.

\section{Summary}

In order to improve the quality of wound care in Kazakhstan critical analysis and energetic actions are required. First of all, there is no statistical monitoring available on the prevalence of chronic wounds and its types, post-treatment complications, and associated costs from the patient and government perspectives. Therefore, it is necessary to develop auniversalmonitoring system for improvement of the system. Secondly, training of medical staff is required to provide patients with the best care. It is required to increase knowledge of the subject among medical personnel, for the safety of patients and prevention of cases where patients are prescribed wide range of unnecessary drugs. Thirdly, the import of new drugs and devices cannot solve the problem, but instead the research, development and production of novel treatments using resources available in the country would be most beneficial. Lastly, there is a huge need for using modern microbiological methods for easier and faster determination of wound contaminants.

There seem to be no approved protocols for wound care in Kazakhstan, which requires their development and further application in practice. Only a few specialists tried to address this problem and proposed the therapeutic strategies [5, 54, 55].

Moreover, there are additional barriers that need to be addressed beforehand. The lack of English language knowledge and lack of access to international level of science and medical databases restrict the ability of the medical staff and researchers to self-education and to keep up with the progress in the field. Activities aimed at increasing the overall awareness of chronic 
wounds and available treatment options for public and medical staff are required.

\section{Acknowledgements}

Authors acknowledge financial support of the project "Carbonpolymer dressings for the treatment of chronic ulcers" by the Ministry of Education and Science of the Republic of Kazakhstan, FP7-PEOPLE-2010IRSES project "Evolving Nanocarbon Strategies in (bio-) Organic Remits" (ENSOR), PIRSES-GA-2010-269267, and the Russian Government Programme of Competitive Growth of Kazan Federal University. Authors thank Dr. Timur Abdulin, Kazan University, for useful discussions.

\section{Conflict of interest}

The authors declare that they have no competing interests.

\section{Authors' contributions}

$A A, T S, G K, T N$ and SM jointly contributed to the design of the study, acquisition and analysis of the data. In particular, AA, TS, GK were responsible for drafting the manuscript. TN and SM mainly contributed to data interpretation and critical revision the manuscript. All co-authors have read and approved the final variant of the manuscript.

\section{References}

1. Kirketerp-Moller K, Jensen PO, Fazli M, Madsen KG, Pedersen J, Moser $C$, et al. Distribution, organization, and ecology of bacteria in chronic wounds. J Clin Microbiol 2008; 46(8): 2717-2722. (doi: 10.1128/JCM.00501-08) (PMID: 18508940) (PMCID: PMC2519454)

2. Werdin $F$, Tennenhaus $M$, Schaller HE, Rennekampff HO. Evidencebased management strategies for treatment of chronic wounds. Eplasty 2009; 9: e19. (PMID: 19578487) (PMCID: PMC2691645)

3. Falanga V. Wound healing and its impairment in the diabetic foot. Lancet 2005, 366(9498): 1736-1743. (PMID: 16291068) (doi: 10.1016/S0140-6736(05)67700-8)

4. Guo S, DiPietro LA. Factors affecting wound healing. J Dent Res 2010; 89(3): 219-229. (doi: 10.1177/0022034509359125)

5. Negemedjanov MS. Experience of treating patientswith purulentnecrotic injuries of lower extremities during pancreatic diabetes. Medicine (Kazakhstan) 2011; 3(105): 30-31.

6. Sabirova N. Level and structure of diabetes mellitus in Kazakhstan and after border countries. Vestnik KazNMU (Kazakhstan) 2013; 1: 228231.

7. Diabetes in Kazakhstan, 2013 http://www.idf.org/membership/eur/kazakhstan

8. Boulton AJ. The diabetic foot: grand overview, epidemiology and pathogenesis. Diabetes Metab Res Rev 2008; 24, Suppl 1: S3-S6. (doi: 10.1002/dmrr.833)

9. Eming SA, Krieg T, Davidson JM. Inflammation in wound repair: molecular and cellular mechanisms. J Invest Dermatol 2007; 127(3): 514-525. (doi: 10.1038/sj.jid.5700701)

10. Peter Lorenz H. MTL: Wounds: Biology, Pathology, and Management. In: Surgery Basic Science and Clinical Evidence. 2nd edition. A. Jeffrey P.S.B. Norton, R. Randal Bollinger, etc. eds. New York: Springer, 2008: 191-208.

11. Diegelmann RF, Evans MC. Wound healing: an overview of acute, fibrotic and delayed healing. Front Biosci 2004; 9: 283-289. (PMID: 14766366)

12. Park NJ, Allen L, Driver VR. Updating on understanding and managing chronic wound. Dermatol Ther 2013; 26(3): 236-256. (doi: 10.1111/dth.12052)

13. Powers JG, Morton LM, Phillips TJ. Dressings for chronic wounds. Dermatol Ther 2013; 26(3): 197-206. (doi: 10.1111/dth.12055)
14. Boateng JS, Matthews KH, Stevens HN, Eccleston GM. Wound healing dressings and drug delivery systems: a review. J Pharm Sci 2008; 97(8): 2892-2923. (doi: 10.1002/jps.21210)

15. Kerihuel JC. Effect of activated charcoal dressings on healing outcomes of chronic wounds. J Wound Care 2010, 19(5): 208, 210-202, 214-205. (doi: 10.12968/jowc.2010.19.5.48047)

16. Sornakumar L, Kalarani M, Srinivas CR. Activated charcoal dressing in malodorous leg ulcers. Indian J Lepr 2010, 82(3): 147-148. (PMID: 21449226)

17. Lo SF, Hayter M, Chang CJ, Hu WY, Lee LL. A systematic review of silver-releasing dressings in the management of infected chronic wounds. J Clin Nurs 2008; 17(15): 1973-1985. (doi: 10.1111/j.13652702.2007.02264.x)

18. Muller $G$, Winkler $Y$, Kramer A. Antibacterial activity and endotoxinbinding capacity of Actisorb Silver 220. J Hosp Infect 2003, 53(3):211 214. (doi: 10.1053/jhin.2002.1369)

19. Moore K, Thomas A, Harding KG. lodine released from the wound dressing lodosorb modulates the secretion of cytokines by human macrophages responding to bacterial lipopolysaccharide. Int J Biochem Cell Biol 1997; 29(1): 163-171. (doi: 10.1016/S1357-2725(96)00128-8)

20. Mertz PM, Oliveira-Gandia MF, Davis SC. The evaluation of a cadexomer iodine wound dressing on methicillin resistant Staphylococcus aureus (MRSA) in acute wounds. Dermatol Surg 1999; 25(2): 89-93. (doi: 10.1046/j.1524-4725.1999.08055.x)

21. Stephen-Haynes J. Evaluation of a honey-impregnated tulle dressing in primary care. Br J Community Nurs 2004; Suppl: S21-S27. (PMID: 15269653)

22. Bale $\mathrm{S}$, Tebbie N, Price P. A topical metronidazole gel used to treat malodorous wounds. Br J Nurs 2004; 13(11): S4-S11. (doi: 10.12968/bjon.2004.13.Sup2.13233)

23. Finlay IG, Bowszyc J, Ramlau C, Gwiezdzinski Z. The effect of topical $0.75 \%$ metronidazole gel on malodorous cutaneous ulcers. J Pain Symptom Manage 1996; 11(3):158-162. (doi: 10.1016/08853924(95)00164-6)

24. Paul JC, Pieper BA. Topical metronidazole for the treatment of wound odor: a review of the literature. Ostomy Wound Manage 2008; 54(3): 18-27. (PMID: 18382045)

25. Vandamme L, Heyneman A, Hoeksema H, Verbelen J, Monstrey S. Honey in modern wound care: A systematic review. Burns 2013; 39(8): 1514-1525. (doi: 10.1016/j.burns.2013.06.014)

26. Gethin G, Cowman S. Case series of use of Manuka honey in leg ulceration. Int Wound J 2005; 2(1):10-15. (doi: 10.1111/j.17424801.2005.00078.x)

27. Chuangsuwanich A, Chortrakarnkij P, Kangwanpoom J. Costeffectiveness analysis in comparing alginate silver dressing with silver zinc sulfadiazine cream in the treatment of pressure ulcers. Arch Plast Surg 2013; 40(5): 589-596. (doi: 10.5999/aps.2013.40.5.589)

28. Ladin D. Becaplermin gel (PDGF-BB) as topical wound therapy. Plast Reconstr Surg 2000; 105(3): 1230-1231. (PMID: 10724287)

29. Hansson C. The effects of cadexomer iodine paste in the treatment of venous leg ulcers compared with hydrocolloid dressing and paraffin gauze dressing. Cadexomer lodine Study Group. Int I Dermatol 1998; 37(5): 390-396. (doi: 10.1046/j.1365-4362.1998.00415.x)

30. Murandu M, Webber MA, Simms MH, Dealey C. Use of granulated sugar therapy in the management of sloughy or necrotic wounds: a pilot study. I Wound Care 2011; 20(5): 206, 208, 210 passim. (doi: 10.12968/jowc.2011.20.5.206)

31. Kilic A. Healing of diabetic ulcers with granulated sugar. Plast Reconstr Surg 2001; 108(2): 585. (PMID: 11496223)

32. Chirife J, Herszage L, Joseph A, Kohn ES. In vitro study of bacterial growth inhibition in concentrated sugar solutions: microbiological basis for the use of sugar in treating infected wounds. Antimicrob Agents Chemother 1983; 23(5): 766-773. (PMID: 6870223) (PMCID: PMC184812) 
33. Lipsky BA, Hoey C. Topical Antimicrobial Therapy for Treating Chronic Wounds. Clin Infect Dis 2009; 49(10): 1541-1549. (doi: 10.1086/644732)

34. James GA, Swogger E, Wolcott R, Pulcini E, Secor P, Sestrich J, et al. Biofilms in chronic wounds. Wound Repair Regen 2008; 16(1): 37-44. (doi: 10.1111/j.1524-475X.2007.00321.x)

35. Maddocks SE, Lopez MS, Rowlands RS, Cooper RA. Manuka honey inhibits the development of Streptococcus pyogenes biofilms and causes reduced expression of two fibronectin binding proteins. Microbiology 2012; 158(Pt 3): 781-790. (doi: 10.1099/mic.0.053959-0)

36. Danielsen L, Cherry GW, Harding K, Rollman O. Cadexomer iodine in ulcers colonised by Pseudomonas aeruginosa. J Wound Care 1997; 6(4): 169-172. (PMID: 9256715)

37. Cho KH, Park JE, Osaka T, Park SG. The study of antimicrobial activity and preservative effects of nanosilver ingredient. Electrochimica Acta 2005; 51(5): 956-960.

38. Lazareth I, Ourabah Z, Senet P, Cartier H, Sauvadet A, Bohbot S. Evaluation of a new silver foam dressing in patients with critically colonised venous leg ulcers. J Wound Care 2007; 16(3): 129-132. (doi: 10.12968/jowc.2007.16.3.27015)

39. Percival SL, Bowler PG, Russell D. Bacterial resistance to silver in wound care. J Hosp Infect 2005; 60(1): 1-7. (doi: 10.1016/j.jhin.2004.11.014)

40. Kulzhanov M, Rechel B. Kazakhstan: Health System Review. Health Systemsin Transition 2007; 9(7): 1-158.

41. Nuralin RSh. Analysys of public opinion about the problem of diabetic foot syndrome in Almaty city and Almaty region. In: Book of The IV Congress of specialists in healthy life style with international participation "Health of the nation is the foundation of our future». Almaty, 2013: 76-78.

42. Kassymova SB, Akhmetova SB, Sergaliev TS, Shakeev KT. The creation of the diabetic foot cabinet for preventive measures and health assessment of patient with diabetic foot syndrome. KazNU Bulletin. Biology series (Kazakhstan) 2014; 1(60): 116-117.

43. Bekmoldina B. Microflora of festering wounds and trophic ulcers monitoring during herbal therapy. Astana Medical Journal 2012; 4(72): 134-137.

44. Doshchanova R. Application of polarized light (generated by the lamp «Bioptron») for complex therapy of tropic ulcers. Vestnik KazNMU (Kazakhstan) 2013; 2: 34-37.

45. Kaupov B, Muratov K, Oralbay A, Kanaev R. Treatment of trophic ulcers of a venous etiology with use of cellular technologies in out-patient conditions. Astana Medical Journal 2012; 1(69): 150-153.

46. Kustova TS, Karpenyuk TA, Goncharova AV, Solomko VP, Iskakbayeva ZhA. Identification of microorganisms in wound surface of patients with pyonecrotic forms of diabetic foot syndrome for development of herbal medicine. KazNU Bulletin. Biology series (Kazakhstan) 2014; 1(60): 126-129.

47. Dzhumagaliev YuK. Sergical treatment of septic wounds in the conditions of an outpatient facility. Medicine. Surgery chapter (Kazakhstan) 2012; 9: 46-47.

48. Muchambetov D, Gurtcaya G, Kasimov A, Rachmadieva S, Anuarbekov A. The estimation of efficiency wound healed effect of phytopreparations. Astana Medical Journal 2011; 6(68): 100-103.

49. Rakhmadieva SB. Hydrolyzable tanning substances of plants and perspectives of their use. In: Book of the $\mathrm{V}$ National Russian research conference on chemistry and technology of plant substances. Russia, 2008: 52.

50. Rakhmadieva SB. Microbiological rationale for the use of Suttigen ointment in the complex therapy of purulent wounds. In: Book of the $\mathrm{V}$ National Russian research conference on chemistry and technology of plant substances. Russia, 2008: 246

51. Sembiev GJ, Utetleuev AM, Baktybaev GS, Nurbekov ES, Esenaliev GK. Treatment of trophical wound with "Regen-D 150". Vestnik KazNMU (Kazakhstan) 2012; 3: 191-192.
52. Zhyzenov AA. A new low-toxicity antiseptic ointment. Medicine 2008; 5: 58-59.

53. Abdullaev MSh, Djuvashev $A B$, Kalenbaev MA. Ultrasound cavitation in complex treatment of purulo-necrotic wounds. Medicine 2011; 10: 1213

54. Sailau Zh, Akhmetova SB, Abdulina GA. Principles of rational antibiotic therapy in different clinical forms of diabetic foot. KazNU Bulletin. Biology series (Kazakhstan) 2014; 1(60): 161-163.

55. Ibadildin AS, Seisembaev MA, Apsatarov EA, Alimzhanov AK, Golovnya MA. Diabetic foot syndrome. Complex treatment. Terapevtichesky Vestnik (Kazakhstan) 2010; 2: 116-117.

56. Abdikadirov AA. Analysis of Vasoprastan application in combination of ischemia at diabetic foot. Medicine (Kazakhstan) 2011; 8: 93-94.

57. Nuralin RSh. Wunatitative assessment of ultrasonic Doppler blood flow velocity signals of lower extremities in patients with diabetic foot syndrome. Medicine (Kazakhstan) 2005; 11: 41-44

58. Sultanaliev TA, Kospanov NA, Pazylov SB, Akanov EK, Kirgizbaev SZh, Matkerimov A.Zh., Genakhunova G.I. Halidor in complex treatment of patients with ischemic diabetic foot. Medicine (Kazakhstan) 2008; 4 56-59.

59. Baymagambetov SA, Koshenov KM. Surgical aftertreatment ill with infectected defects of mild tissues of autopodium. Medicine (Kazakhstan) 2007; 9: 5-6.

\section{Authors:}

Alma Akhmetova - BSc, Junior research fellow, Department for Translational Medicine, Longevity and Global Health, Centre for Life Sciences, Nazarbayev University, Astana, Kazakhstan.

Timur Saliev - PhD, MD, Director of Department of Regenerative Medicine and Artificial Organs, Centre for Life Sciences, Nazarbayev University, Astana, Kazakhstan.

Gulsim Kulsharova - BSc, MS, Teaching assistant, School of Engineering Nazarbayev University, Astana, Kazakhstan.

Talgat Nurgozhin - MD, Professor, Director of the Department for Translational Medicine, Longevity and Global Health, Centre for Life Sciences, Nazarbayev University, Astana, Kazakhstan.

Sergey Mikhalovsky - PhD, Vice Dean of Research, School of Engineering Nazarbayev University, Astana, Kazakhstan; Professor of Materials Chemistry, School of Pharmacy and Biomolecular Sciences, University of Brighton, Cockcroft Building, Lewes Road, Brighton, BN2 4GJ, United Kingdom. 